\title{
貯水池堆砂量予測のための 土砂動態モデルの開発と光の適用 DEVELOPMENT OF A SEDIMENT RUNOFF MODEL TO PREDICT RESERVOIR SEDIMENTATION AND ITS APPLICATION
}

\author{
河田暢亮 ${ }^{1}$ 藤田正治 ${ }^{2} \cdot$ 竹林洋史 ${ }^{3}$ \\ 吉野秀樹 4 -平林桂 5 \\ Nobuaki KAWATA, Masaharu FUJITA, Hiroshi TAKEBAYASHI, \\ Hideki YOSHINO and Katsura HIRABAYASHI

\begin{abstract}
1正会員 工修 電源開発株 $)$ 土木建築部 （=104-8165 東京都中央区銀座6-15-1）
2正会員 工博 京都大学教授 防災研究所（干612-8235 京都府京都市伏見区横大路下三栖東八口）。

3正会員 工博 京都大学准教授 防災研究所（二 $612-8235$ 京都府京都市伏見区横大路下三栖東ノ口）

4正会員 株)開発設計コンサルタント 土木事業本部（テ101-0021 東京都千代田区外神田2-16-2）

5 工博 株甲府水研（广400-0035 山梨県甲府市飯田2-14-15）
\end{abstract}

In this paper the authors propose a practical sediment runoff model with soil production process considering slope failure as well as weathering by freezing and thawing. One of the main features of the model is to consider the actual conditions and experiences of the slope failure in the reservoir basin. The authors try to clarify applicability of the model in case of J-POWER's dams and evaluate the effects of the climate change to reservoir sedimentation. As a result, the progress of reservoir sedimentation at some of J-POWER's dam sites is estimated to be accelerated by climate change.

Key Words : Reservoir sedimentation, Soil production and transportation, Sediment runoff model, Climate change, Slope failure, Freeze-thaw

\section{1.はじめに}

貯水池の堆砂問題は年々深刻化を増しており，地球温 暖化による降雨条件の変化によって斜面崩壊が頻発すれ ば，問題がさらに拡大寸る䀣念も指摘されている ${ }^{11}$. そ の一方で対策の実現には膨大な費用を要するため進捗は 遅れている. このような状況のなか, 効果的な対策を着 実に進めるには将来の堆砂量を的確に予測することが重 要であり, それには, ダムの流域内で土砂が生産され, 貯水池に流入するまでのプロセスをシミュレーションす る流域土砂動態モデルが有用と考えられる.

土砂流出の予測方法については, 砂田ら ${ }^{2)}$, 江頭ら ${ }^{3)}$,

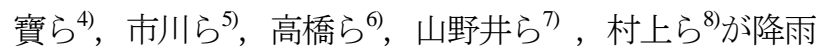
流出モデルと流砂モデルを組み合わせた土砂流出予測モ デルを提案している，江頭ら，高橋らは主にダムの流域 を対象としてモデルの開発を進めており, 森谷・江頭ら 9)は, 斜面の飽和面積と崩壊土量を関連付けて生産土砂 量を求める方法, 高橋ら ${ }^{6}$ は流域に固有の限界降雨線と 裸地斜面侵食深を関連付けて生産土砂量を求める方法を それぞれ案出している。
本研究では, 降雨時の斜面表層崩壊と冬季から春季に かけて起こる凍結融解作用によって生産された土砂が崖 錐を経由して河道に取り込まれる土砂生産モデルを提案 し, 江頭ら ${ }^{3)}$ の土砂輸送モデルと結合して, 貯水池堆砂 量を予測するための新たな流域土砂動態モデルを構築す るとともに, 実際のダム流域に適用して堆砂量の再現計 算を行い, 妥当性の検証, ならびに地球温暖化が堆砂量 に与える影響について検討する。

\section{2．ダム流域における表層崩壊の実態}

検討対象としたのはJ-POWERが河川の最上流に保有 するAダムとBダムであり，はじめに運開年以降（A： 1965年，B：1964年）で既往最大規模以下の降雨に対す る崩壊特性を調査する. 両ダムの主要諸元を表-1に示寸.

表-1 Aダム, Bダムの主要諸元

\begin{tabular}{|c|c|c|c|c|}
\hline & $\begin{array}{c}\text { 流域面積 } \\
\left(\mathrm{km}^{2}\right)\end{array}$ & $\begin{array}{c}\text { 高さ } \\
(\mathrm{m})\end{array}$ & $\begin{array}{c}\text { 総貯水容量 } \\
\left(\times 10^{6} \mathrm{~m}^{3}\right)\end{array}$ & 地質 \\
\hline $\mathrm{A}$ & 69.1 & 32 & 0.5 & $\begin{array}{c}\text { 流紋岩\& 砂岩 (崩壊地) } \\
\text { 安山岩 (その他) }\end{array}$ \\
\hline B & 20.1 & 95 & 14.2 & 中生代後期の砂岩 \\
\hline
\end{tabular}




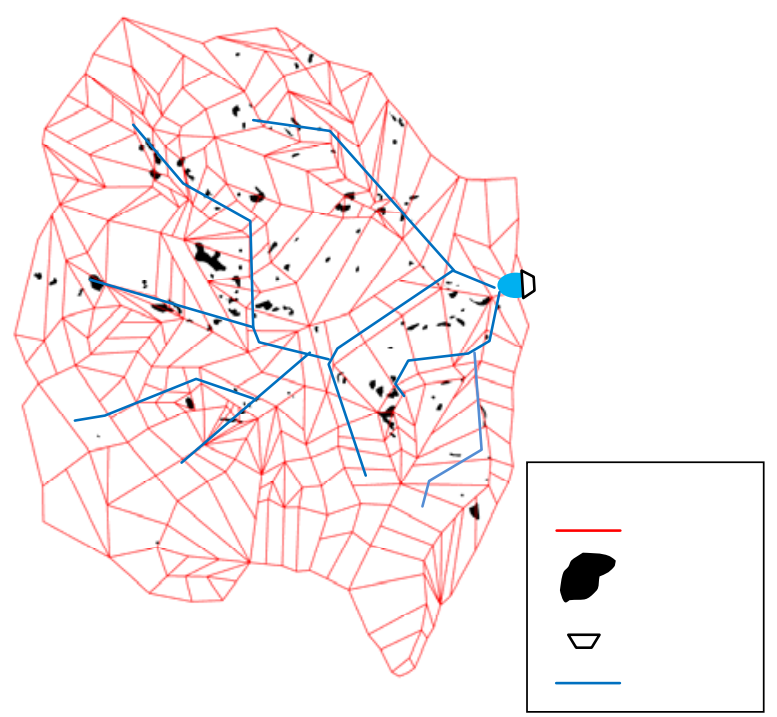

図-1 Aダム流域の崩壊地の分布 $(1998 \rightarrow 2002$ 年)

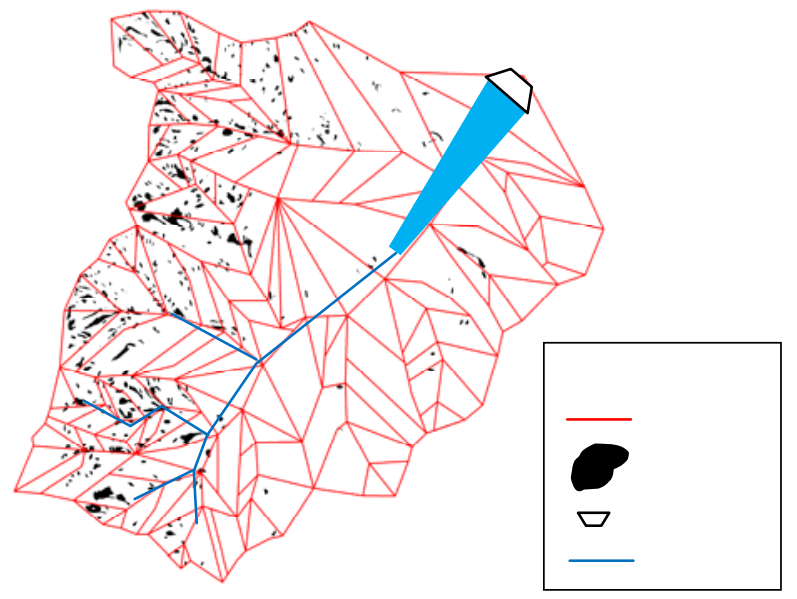

図-2 B久゙ム流域の崩壊地の分布 $(1980 \rightarrow 1990$ 年 $)$

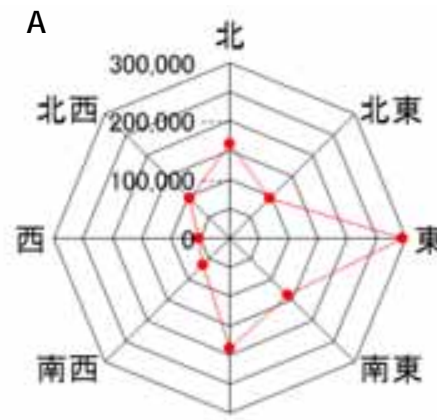

南

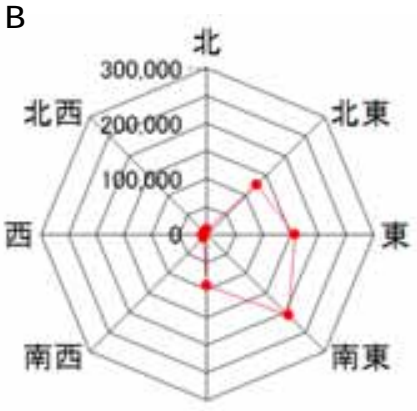

南
図-3 斜面方向別の崩壊面積 (単位 : n²)

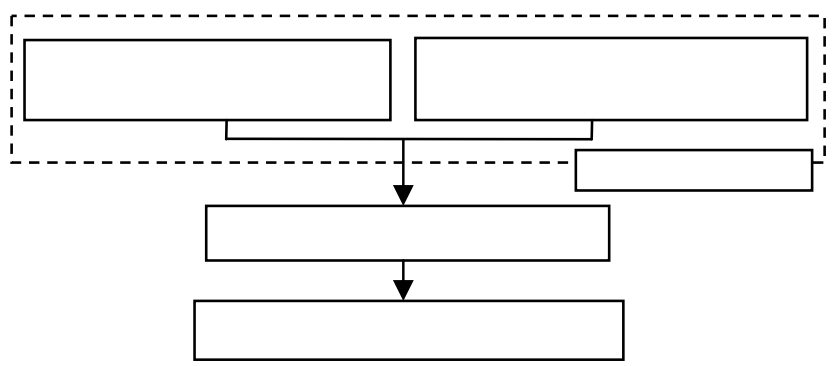

図-4 流域土砂動態モデルの構成
両ダムの流域を江頭らの手法3) で図-1と図-2のように 単位斜面に分割し，既往最大規模の降雨を挟んで撮影し た2枚の航空写真を比較することにより，既往最大規模 以下の降雨で表層崩壊の発生が予想される単位斜面の特 定と単位斜面内の崩壞面積を求め, さらに地形・地質と 崩壊との関係を整理した．Aダムは1998と2002年，Bダ ムは1980と1990年に撮影した写真を用いた。

表層崩壊面積と様々な地形・地質要因との関係のうち 両ダムの流域における単位斜面の方向別崩壊面積を図- 3 に示寸．Aダムの流域では東から南向き斜面で多くの崩 壊が起こっており，Bダムの流域では，南東方向を中心 に北東から南向き斜面に崩壊が集中している，表層崩壊 は様々な地形・地質要因と関係していると考えられるが, このように，結果的には斜面方向との相関が強かった.

これは，昼間，太陽光を強く受ける斜面で，熱の増減に より表層が膨張と収縮を繰り返し，風化の進行が速くな ることや，南から東向き斜面では積雪による断熱効果が 小さく冬季から春季の凍結融解も活発であることが一因 であると思われる，そこで，以下に提案する土砂生産モ デルでは，このような単位斜面の方向による崩壊発生面 積の違いを経験的特性として考慮する。

\section{3．流域土砂動態モデル}

\section{(1) 概要}

本研究の流域土砂動態モデルは図-4のように構成され, いくつか特徵的な点がある. まず土砂生産モデルでは, 斜面崩壊のメカニズムを考慮しつつ, 崩壊地の分布や面 積, 堆砂測量のデータを使って崩壊一回あたりの生産土 砂量と崩壊回数に係るパラメータを実態に合うよう同定 している点である．理論的にパラメータを設定し，実現 象に合うようにするのが理想的であるが，広大で複雑な ダム流域が対象では容易なことではない，本研究では多 少便宜的であっても実用性の高いモデルを目指すことに 重点を置いた．既往最大を超える新たな降雨が発生すれ ば逐次パラメータを見直す必要があるが，崩壊地のデー タや堆砂量のデータがあればモデルを構築できるため, 多くのダムに適用できる可能性がある。 また生産された 土砂が河道付近に堆積して一旦崖錐を形成し，流水によ り侵食されることで河道に供給されることを概念的に表 した土砂供給モデルを導入している点も特徵である.

\section{(2) 降雨流出モデル}

雨の流出過程は降雨観測值を入力条件とする分布型流 出モデルで計算される．流域分割は基本的に尾根に沿っ て行い，単位斜面が三角形または台形になるようにした。 単位斜面は不透水性基岩の上の 1 層モデルとし，その層 厚と透水係数を与えた．単位斜面内には流下方向に沿っ て8つの断面を設定し，この断面上でkinematic wave法に より表面流および中間流の水深と流速を計算した. 


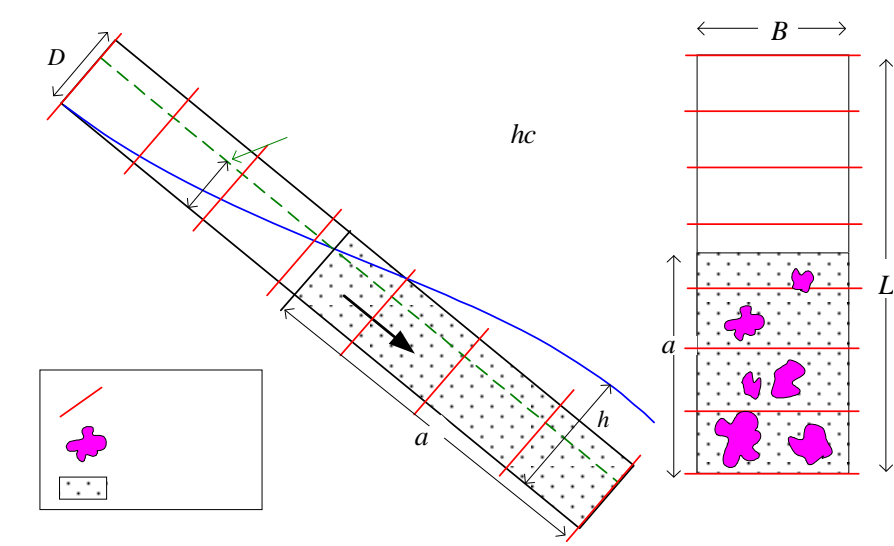

図 5 単位斜面での水面形と表層崩壊の関係

\section{（3）表層崩壞による土砂生産モデル}

(a) 基本的な考え方

一斜面スケールでの降雨による表層崩壊現象は，地形， 土質，降雨条件，土層構造が与えられれば計算できる.

しかし，大きな流域で一斜面スケールの諸データをす心゙ て得ることは難しく，いくつかの斜面で得られた值を他 の斜面に用いても計算精度は保証されない。また，単位 斜面にこの理論を援用することは可能であるが，単位斜 面は複数の斜面を含んでいるため直接単位斜面で複数起 こる表層崩壊の面積を求めることはできない.

そこで本研究では以下のような方法を考えた。すなわ ち，単位斜面内の浸透流解析を行い，不透水性基岩上の 水深がある閾值を超えると，ある崩壊面積率で単位斜面 内に崩壊が発生し，土砂が生産されるものとする．水深 の閾值，すなわち崩壊限界浸透水深 $h_{c}$ は単位斜面に対寸 る無限長斜面の安定解析から理論的に求められるが，崩 壊実態との顽齣をなくすため, 過去の降雨条件と崩壊や 堆砂量の実績から，崩壞の実態が説明できるよう経験的 に決定する．また崩壊面積率の理論解析は難しく，これ についても $h_{c}$ と同様に過去のデータから決定する.

(b) 崩壊土量

図-5に示寸ように単位斜面幅 $B$ を一定とし，水深が崩 壊限界浸透水深を超えた部分の長さを $a$ ，表土層厚を $D$, $C_{o}$ を補正係数とすると，単位斜面ごとの崩壊土量 $V_{c o}$ は (1)式のようになる.

$$
V_{c o}=C_{o} \cdot a \cdot B \cdot D
$$

水面形が直線と仮定すると(1)式は以下のようになる

$$
V_{c o}=C_{o} \cdot L\left(1-\frac{h_{c}}{h_{0}}\right) \cdot B \cdot D=C_{o} \cdot A_{0} \cdot\left(1-\frac{h_{c}}{h_{0}}\right) \cdot D
$$

ここに, $L$ : 単位斜面長, $h_{0}$ : 単位斜面の下流端におけ る不透水性基岩からの水深, $A_{0}$ : 単位斜面面積である.

(2)式により，表土層厚，単位斜面の面積，崩壊限界浸 透水深, 補正係数を与え, 単位斜面下流端の水深を浸透 解析により計算すれば一単位斜面での崩壊土量が計算で きる. ただし，水深は降雨イベント中に時々刻々変化す
るので，土量を求めるタイミングが問題である.ここで は，一降雨ごとに水深の最大值を求め, 最大水深の時点 に対して崩壊発生の有無と土量を解析する。また，引き 続く降雨によって再度崩壊しないように, 便宜的に一度 崩壊したら最低10日間は再発しないとした。

\section{(c) 崩壊限界浸透水深}

崩壊限界浸透水深 $h_{c}$ は崩壊発生の閾值であり, 本モデ ルの実用性を高める重要なパラメータである。今，ある 期間の降雨条件に対して各単位斜面の水深が最大值 $h_{\text {max }}$ に達した時，最も崩壊の危険が高い状態にあるといえる。 結果的に崩壊した斜面では $h_{c}<h_{\max }$ と考えられ，崩壊し なかった斜面は $h_{c}>h_{\text {max }}$ と考えられる. ここに $h_{c}, h_{\text {max }}$ は各単位斜面での值である. そこで $h_{c}=\alpha h_{\max }$ とすると 崩壊発生斜面は $\alpha<1$ ，非発生斜面は $\alpha>1$ と考えることが できる．このように $\alpha$ を設定することで降雨に対する崩 壊発生の再現性は良くなる。 しかし，崩壊しなかった単 位斜面 $(\alpha>1)$ でも, 今後同様の降雨条件で崩壊する可能 性もあるし，当該期間の最大規模を超える降雨では崩壊 することも想定される， $\alpha$ は過去の降雨条件と崩壊や堆 砂量の実績から，崩壊の実態が説明できるように経験的 に決定されるものであるが， $\alpha$ の值は得られたデータの 実態に合わせて，再調整すべきものである.

\section{(d) 補正係数 $C_{o}$ の設定}

単位斜面内の水深が $h_{c}$ に達したとしても，その範囲が すべて崩壊するわけではない. (1), (2)式の $C_{0}$ は一回の降 雨により, 水深が $h_{c} に$ 達した範囲のうち，どれくらいの 割合が崩壊するのか，すなわち崩壊面積率を表す係数で ある。しかし，個々の斜面を単位斜面に統合した時点で $C_{0}$ を理論的に求めることは不可能である. また，この係 数には実際の崩壊深との違いを補正する意味も含まれて いる，そこで， $C_{0}$ を以下のように書き改める.

$$
C_{o}=\beta_{1} \cdot c_{0}
$$

ここに, $c_{0}$ : 崩壊発生時の各単位斜面における崩壊面 積率， $\beta_{1}$ : 補正係数である.

さて $c_{0}$ については，崩壊が発生する降雨ごとに航空写 真があればそれをもとに求めることもできるが，一般的 には撮影頻度はそれよりも少ない，そこで，2 時点の航 空写真がある場合，次のような実用的方法を用いること ができる．まず，2枚の写真を比較し，その間に発生し た崩壊面積 $A_{s}$ を調心，崩壊面積率 $r=A_{8} / A_{0}$ を求める. $r$ は当該期間の後の撮影時点に近い豪雨による崩壊面積率 か, 大規模な降雨による崩壊面積率かを表していると推 察できるが，植生の回復の効果や写真判読できない崩壊 地の存在により(3)式の $c_{0}$ とは異なる. しかしデータが 無い以上， $r$ を解析に用いることにするが，上述の誤差 の原因を考慮して補正係数を導入し， $c_{0}=\beta_{2} r$ として(3) 式を次式のように表す。

$$
C_{o}=\beta_{1} \cdot \beta_{2} \cdot r=C_{1} \cdot r
$$




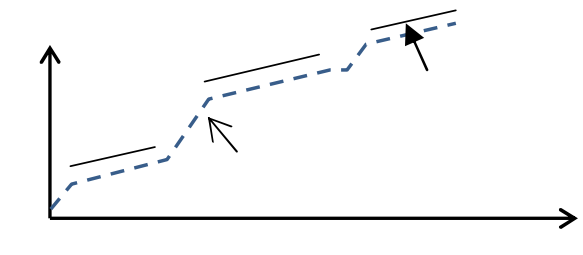

图-6 積算堆砂量の経年変化の一般的な概形

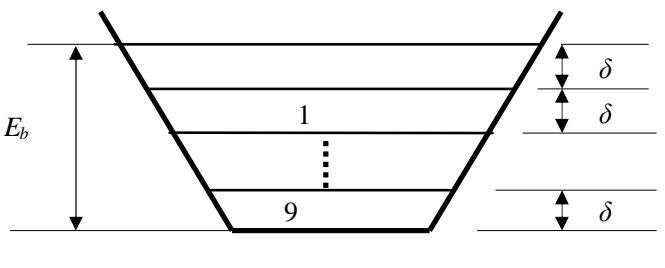

図- 7 河床モデル

表- 2 降雨流出計算のパラメータ

\begin{tabular}{|c|c|c|c|c|}
\hline ダム & 表土層厚 $(\mathrm{cm})$ & 透水係数 $(\mathrm{m} / \mathrm{s})$ & 粗度(流域) & 粗度(河道) \\
\hline $\mathrm{A}$ & 8 & 0.05 & 0.6 & 0.045 \\
\hline $\mathrm{B}$ & 20 & 0.01 & 0.6 & 0.045 \\
\hline
\end{tabular}

(e) 崩壊限界浸透水深および補正係数 $C_{1}$ の算定法

以上より, 崩壊限界浸透水深 $h_{c}$ と補正係数 $C_{1}$ を与え ると単位斜面の浸透流の解析から崩壊のタイミングと土 量を計算できる。これらの值は，航空写真が撮影された 期間の堆砂量についてシミュレーション計算を行い，本 提案の流域土砂動態モデルを使って計算された值と実測 值が概ね一致するように試行錯誤的に求める.

\section{（4）凍結融解による裸地斜面風化基岩の土砂化}

Aダムは北海道，Bダムは北陸地方に位置しており， 両ダムとも凍結融解作用による土砂生産が想定される.

泉山ら ${ }^{10}$ は，凍結融解作用に着目した土砂生産モデル を提案している. 泉山らの方法は, 裸地斜面の風化基岩 における温度分布の解析により凍結融解の凍結融解回数 の深度分布を求め ${ }^{11)}$ ，岩質に応じた土砂化プロセスか ら生産土砂量を算定するものである.

泉山らの方法には，土砂化に要する凍結融解回数や一 回の凍結融解に対寸る剥離厚さなど，土砂生産量に大き く影響するパラメータが含まれている。したがって，実 用性を高めるにはこれらのパラメータを適切に同定する 必要がある. 図-6は一般的に見られる積算堆砂量の経年 変化の概形を示したものである. 多くのダムではこの図 に見られるように堆砂率が小さい期間と大きい期間があ る. 前者は凍結融解作用による通常の土砂生産が寄与し ており，後者はそれに斜面崩壊などの土砂生産現象が影 響しているものと考えることができる. そこで通常の堆 砂率のデータからパラメータの同定を行う.

\section{（5）崖錐の形成と侵食の概念モデル}

生産された土砂は河道の近くに運ばれて崖錐を形成し, 流水による侵食によって河道に供給される. 山野井ら のモデルでは崖錐の消長を計算しているが，本研究では 堆砂量の予測が目的であり, 前述したように多くのパラ メータは堆砂量の実績に合わせて同定している.このこ
とから生産土砂は崖錐の形成（生産土砂の蓄積）と侵食 という過程を通して残留することなくすべて徐々に河道 に供給されるとする．土砂の供給は供給点の単位河道の 河床位を一定速度で上昇させる方法で行い，崖錐が当該 降雨期間中に消失し，かつ計算が安定するように試行錯 誤的に速度を設定した.

\section{(6) 土砂の輸送モデル}

土砂の輸送モデルは江頭ら ${ }^{3)}$ の研究を参考にして, 次 のように組み立てた．単位河道は実際の河道に沿って設 置し，区分点は河床勾配の変化点としたが，区間が長す ぎる場合は区間内に区分点を設けて単位河道長が大きく ならないようにした，河道断面は台形とし，河床位は河 道上流端の標高で代表させ，勾配は直下流の単位河道の 標高との差から求めた，流れは等流とし，Manningの平 均流速式により単位河道の水深を計算した. 単位河道か ら流出する流砂量は水深，勾配，河床材料の粒度分布か ら計算した。 河幅は各単位河道下流端の流域面積に応じ て笠井ら ${ }^{12)}$ の提案したレジーム則で与えた。掃流砂量の 計算はKovacsの補正を加えた粒径別芦田・道上式 ${ }^{13}$ に よった。浮遊砂量の計算は粒径別基準面濃度式にLaneKalinske式を用い，浮遊砂の移流方程式を解く過程で河 床からの上昇・河床への下降フラックスを求める非平衡 モデル ${ }^{14)}$ に基づいた. 粒度分布の計算は台形断面に拡張 した平野モデル15)を用いた. 図-7のように初期河床の下 に交換層と9層のメモリー層、その下に岩盤が露出する と仮定し，河床が低下して河床面と岩盤との距離が交換 層厚よりも小さくなった時には, 以下の竹林らの方法 ${ }^{16)}$ に従い流砂量を補正した。 なお交換層とメモリ一層の厚 さは河床材料の最大粒径程度の $25 \mathrm{~cm}$ とした.

$$
\begin{aligned}
& q_{s k}=f\left(\varphi_{1}, \varphi_{2}\right) \cdot r_{b} \\
& r_{b}=\left\{\begin{array}{cc}
1 & E_{b} \geq \delta \\
E_{b} / \delta & E_{b}<\delta
\end{array}\right.
\end{aligned}
$$

ここに， $q_{s k}$ : 粒径階層 $k$ の掃流砂量あるいは浮遊砂量, $f:$ 粒径別掃流砂量式あるいは浮遊砂基準面濃度式， $\phi_{1}$, $\phi_{2}$ : それぞれ河床材料, 水理量の特性量, $r_{b}$ : 河床材料 の存在率, $E_{b}$ : 堆積層厚, $\delta$ : 交換層および各メモリー 層の層厚であり，岩盤河床上の河床材料の堆積層厚が交 換層厚を下回った場合には，河床材料の存在率の減少に 伴い流砂量が減少することを考慮したものである.

\section{AダムおよびBダム流域への適用}

\section{(1) パラメータの同定}

(a) 降雨流出計算のパラメータ

実測流量と雨量を用い，代表的な洪水時の貯水池流入 量の計算值と実測值が概礼一致するようパラメータを調 整した結果，表-2のようになった．表土層厚は通常の実 際の值より少し小さい值であるが，単位斜面を用いた計 算であり，実斜面との違いが表れたものと思われる. 

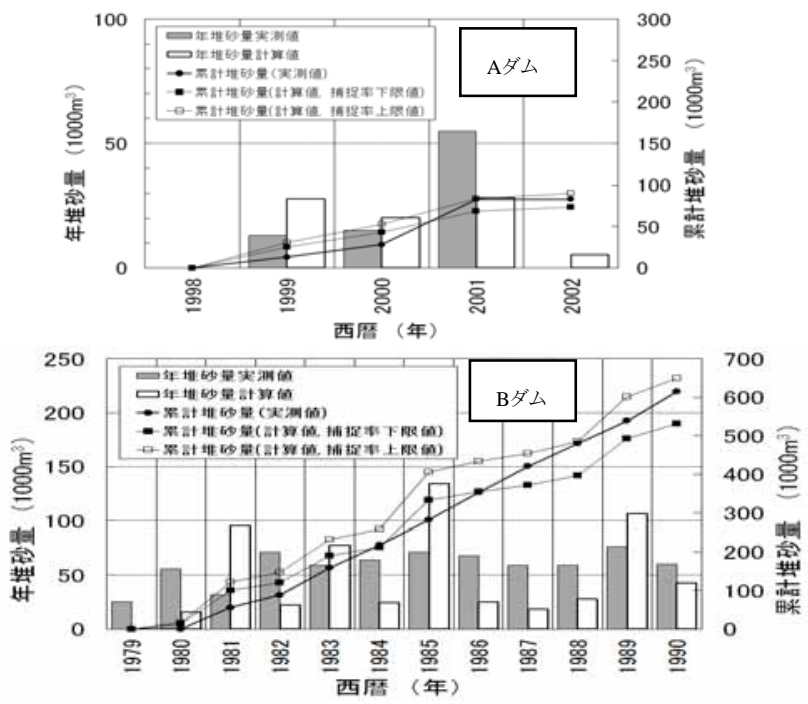

图-8 堆砂量の実測值と計算値の比較 (写真撮影期間)

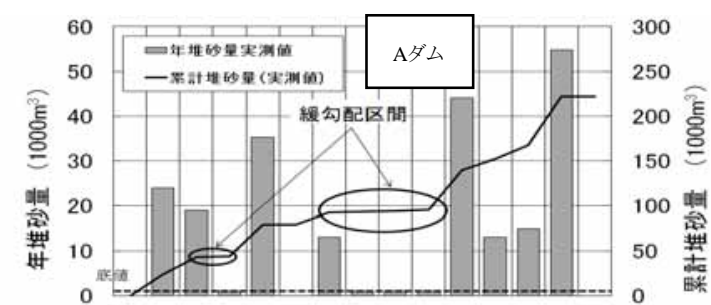

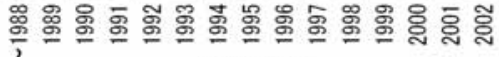

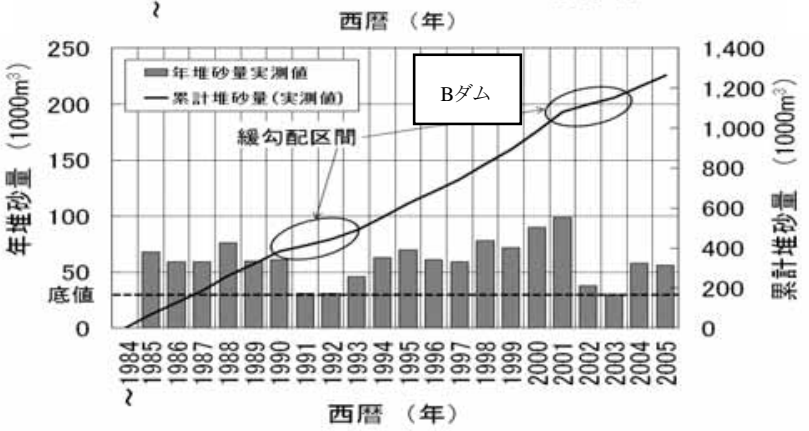

図-9 堆砂量実測值の経年変化

(b) $C_{1}$ と $\alpha$ の同定

Aダムは1998 と2004年，Bダムは1980と1990年の写真 により, 崩壊発生単位斜面と斜面方向別崩壊面積率 $r$ を求め, 堆砂量の計算值と実測值を比較して $\alpha$ と $C_{1}$ を 試行錯誤的に決定する． $\alpha$ は土砂生産の頻度を支配する ので，最初にこれを調整する．崩壊が無い年や少ない年 はなるべくそうなるようにする，続いて $C_{1}$ を調整し， 累計堆砂量が合うようにする，ただし崩壊しなかった斜 面は $\alpha$ を1以上に設定する. 堆砂量の計算值と実測值の 比較が図-8であり, 単年毎で多少違いはあるが，Aダム は $C_{1}=500, \alpha=0.65, \mathrm{~B} タ ゙ ム は C_{1}=300, \alpha=0.85$ で両者は 概ね一致した. $r$ は単位斜面毎に与えており， 2 .に示し た方向別の崩壊のしやすさが反映されている． $C_{1}$ の值は 定義からすると過大と思われるが，表土層厚が降雨流出 計算の再現性のため小さく設定され崩壊深が実際より小 さいと考えられること, 写真間隔が離れており崩壊面積 率が明確でないこと，写真で判別できない崩壊地がある
こと，供給土砂の河道貯留などがそうなった理由として 挙げられ，これらはさらに検討すべき課題である.

本手法は新たな崩壊でデータが蓄積されるに伴い， $\alpha$ や $C_{1}$ を更新し, 次の予測に役立てるのが基本的考え方 である．降雨規模が再現計算時より大きくなれば，過去 に崩壊しなかった斜面の崩壊もあり得るため, 予測計算 では，再現計算で崩壊しなかった斜面の $\alpha$ や $r$ の与え 方が問題になる. $r$ は崩壊した斜面の值を用いるのが妥 当と考えられるが， $\alpha$ は1に近くして安全側予測とする のか，1より離して危険側予測とするのか判断を要する. ここでは，再現期間に崩壊しなかった斜面は地形地質的 に崩壊しにくかったとして $\alpha=2$ と設定するが，降雨規模 の更新に伴い，設定值の検討と修正は不可欠である.

(c) 凍結融解モデルのパラメータの同定

Aダムは流紋岩と砂岩に崩壊地が多く, Bダムは流域 の大部分が砂岩であるため, 泉山の方法 ${ }^{10)} に よ り$ 風化基 岩表面の凍結融解ごとにある剥離厚さで土砂化するとす る. 剥離厚さを砂の粒径程度の $0.25 \mathrm{~mm}$ とした場合, Aダ ム約 $6,000 \mathrm{~m}^{3}, \mathrm{~B} タ ゙ ム$ 約 $10,000 \mathrm{~m}^{3}$ の年土砂生産量となった. 一方，堆砂量経年変化を示した図 9 では，Aダム $1,000 \mathrm{~m}^{3}$, Bダム $40,000 \mathrm{~m}^{3}$ と推定される. 両者で值は異なるが， A ダムとBダムともにオーダー的には一致しており, 以上 のパラメータ設定はある程度妥当であると考えられる.

（d）崖錐からの土砂供給に関するパラメータ

崖錐からの土砂供給による河床上昇速度は, 両ダムと もに $0.0005 \mathrm{~m} / \mathrm{sec}$ した. これを多少変動させても堆砂量 への影響が少ないのを確認している．また土砂の粒度は 当該単位河道の初期河床材料の粒度分布と同じとした.

\section{（2）堆砂量再現計算}

長期間の堆砂量再現計算の結果が図- 10である。

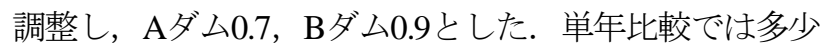
傾向が異なるが，経年変化では実測值と計算值がほぼ一 致し, 堆砂量の変化をある程度の精度で再現できた.
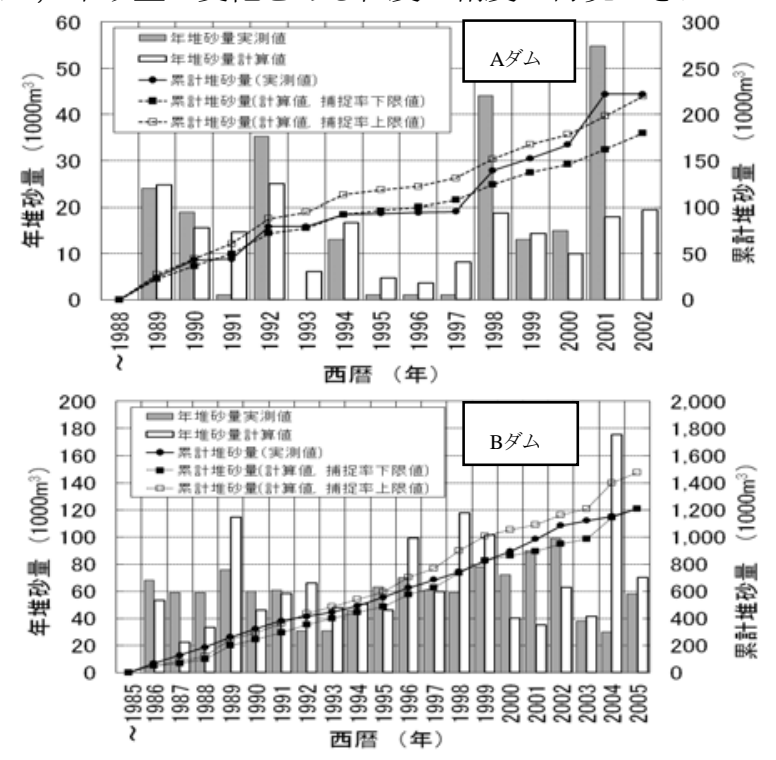

图-10 堆砂量の実測值と計算値の比較 (長期間) 


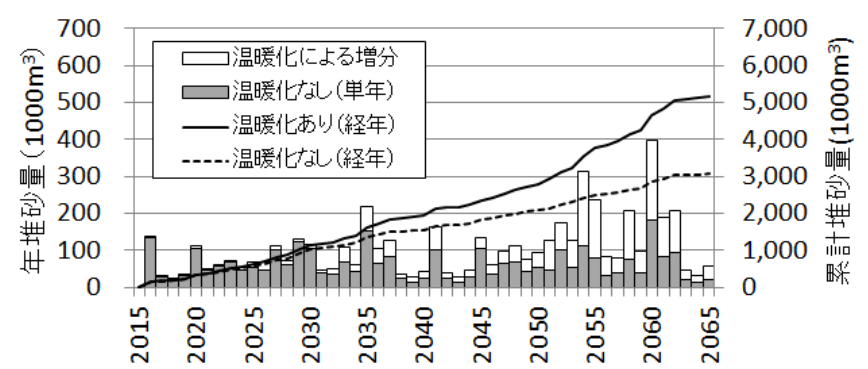

図-11 温暖化の堆砂進行への影響 (B父ム)

崩壊土の粒度分布の与え方, 堆砂測量の精度の問題等 もあり，単年ごとの結果まで整合させるのは容易ではな いが，適切なパラメータ設定により，ある程度の精度で 本モデルが適用できることを確認した.

\section{5 . 地球温暖化の堆砂への影響予測}

和田ら ${ }^{177}$ は地域気候モデルで2031〜2050年の我が国の 気候予測を実施した。これによれば，ほぼ全国的に年降 水量が増加し, 近畿, 東海から北陸など増加率が $40 \%$ 以 上となる地域もある. よって年降水量が一定割合で増加 し，50年後に1.5倍になると仮定した計算を実施する.

また気温上昇で涷結融解回数が減ると, 土砂生産量は 減少すると推測される. 気温が現在より $5^{\circ} \mathrm{C}$ 上昇すると 仮定し，泉山の方法でBダムの生産量を試算した結果， 現在から約60\%減ったことから，凍結融解による生産量 は50年で40,000から $24,000 \mathrm{~m}^{3}$ に直線的に減少するとした。 図-11はBダムについて温暖化ありなしの場合を比較し 結果であり, 温暖化で堆砂進行が約2倍加速すると予測 された. 当初約10年は凍結融解分の減少で降雨分の増加 が相殺されるが，その後増加は加速する．降雨増により 崩壊する斜面数や回数の増加がその主因と考えられる.

\section{6.まとめ}

過去の表層崩壊の実態, 貯水池堆砂のデータを使って 構築した流域土砂動態モデルを実際のダムに適用した結 果, ある程度の精度で堆砂量の変化を再現できることを 確認した. また堆砂への温暖化影響を予測した結果, ダ ムによっては堆砂の進行が加速的になることがわかった。 一方で, 本モデルの発展には流域のデータが重要であり, 新たな崩壊が起こり, データが蓄積されるに伴い, 恒常 的にパラメータを更新していく必要がある.

\section{参考文献}

1) 温暖化影響総合予測プロジェクトチーム：地球温暖化「日 本一の影響」一最新の科学的知見一, 2008

2) 砂田憲吾・長谷川登 : 国土数值情報に基づく山地河川水系 全体における土砂動態のモデル化の試み，土木学会論文集，
485/ ПI-26, pp.37-44， 1994

3) 江頭進治，松木 敬 : 河道盯留土砂を対象とした流出土砂 の予測法，水工学論文集，第44巻，pp.735-740，2000

4) Takara, K. , K. Notsumata and R. Uesaka : A Distributed Model for Flood Runoff and Sediment Yield Based on Remote Sensing and GIS, Symposium on Japan-Indonesia IDNDR Project, September 21-23, 1998, Bandung, Indonesia, pp.373-384, 1998

5) 市川温, 佐藤康弘, 椎葉充晴, 立川康人, 寶馨 : 山地流域 における水・土砂動態モデルの構築, 京都大学防災研究所 年報, Vol..42 B-2, pp.211-224, 1999

6) 高橋保，井上素行，中川一，里深好文 : 山岳流域からの土 砂流出モデルを用いた貯水池堆砂の予測, 水工学論文集, Vol.45, 841-846, 2001

7) 山野井一輝, 藤田正治 : 土砂生産 - 土砂供給・土砂輸送堆 積統合型モデルの開発と山地流域一の適用，土木学会論文 集B1(水工学)，Vol.70，No.4，I_925-I930，2014

8) 村上正吾, 林誠二, 亀山哲, 渡辺正孝 : 河川流域内農林地 域における土砂動態モデルに関する基礎的検討，水工学論 文集，Vol.45，799-804，2001

9) 森谷崇正, 江頭進治, 伊藤隆郭, 谷貴也 : 崩壊 -土石流に よる河道貯留土砂を考慮した土砂流出予測法に関する研究, 関西支部年次学術講演会講演概要集, II-27-1-II-27-2. 2005

10) 泉山寛明 : 風化基岩における凍結融解による土砂生産プ ロセスとそのモデル化に関する研究，京大博士論文，2012

11) 堤大三，藤田正治，伊藤元洋，手島宏之，澤田豊明，小 杉賢一郎, 水山高久 : 凍結融解による土砂生産に関する基 礎的研究一田上山地裸地斜面における現地観測と数值シ ミュレーションー, 砂防学会誌59(6), pp3-13, 2007

12）笠井美青 : 嘉瀬川ダムに流入する河川およびダムへの流 入土砂について, 平成 $9 \sim 11$ 年度建設省・土木学会共同研 究報告書（代表 : 九州大学 橋本晴行），2000

13) 芦田和男, 道上正規 : 移動床流れの抵抗と掃流砂量に関 する基礎的研究，土木学会論文報告集，No.206， pp.59-69, 1972

14) Egashira, S., Ito, T., Horie, K. and Nishimoto, N A method to predict sediment transport process in drainage basin with dams, RCEM 2007, Dohmen-Janssen \& Hulscher (eds), Taylor \& Francis Group, ISBN 978-0-415-45363-9, pp. 27-36, 2005

15) 平野宗夫 : Armoring を伴う河床低下について, 土木学会 論文報告集，第195 号，1971 年11 月

16) Hiroshi Takebayashi, Shinji Egashira and Haisheng Jin : Effect of sediment sorting on geomorphologic characteristics of alternate bars, Proc. $27^{\text {th }}$ Congress of IAHR, Theme B, pp.1433-1438, 1997

17) 和田一範 - 川崎秀明・村瀬勝彦・冨澤洋介 ・ 尾瀬智昭 石原幸司・栗原和夫 : 地球温暖化に伴う降雨特性変化に関 寸る共同研究，国土技術政策総合研究所資料，第320号， 2004年3月.

(2015. 9. 30受付) 